\title{
Validation of categories of the International Classification of Functioning, Disability and Health for the elderly
}

\author{
Validação de categorias da Classificação Internacional de Funcionalidade, Incapacidade e \\ Saúde para pessoas idosas
}

Silvana Sidney Costa Santos ${ }^{1}$, Silomar Ilha ${ }^{1}$, Edison Luiz Devos Barlem ${ }^{1}$, Daiane Porto Gautério-Abreu ${ }^{1}$, Bárbara Tarouco da Silva ${ }^{1}$, Inaiá Santos Alves ${ }^{2}$

Objective: to validate categories of the International Classification of Functioning, Disability and Health directed
to the elderly. Methods: methodological study of 13 Brazilian gerontologist nurses. We used an electronic form
based on the International Classification of Functioning, Disability and Health, composed of 107 items ( 45
related to Body functions, 38 to Participation and Activity; 24 to Environment). The form was forwarded by
email. The items were evaluated on a Likert scale of five points ranging from 0 to 1.0 . Questions with $80.0 \%$ and
more than $80.0 \%$ of appearance. Results: participants validated 21 categories related to Body Functions; 18
categories related to Participation and Activity; three categories related to Environmental Factors. Conclusion:
biomedical training in nursing may have directed the preferential validation of categories related to the body
and less preference to context/environment. Descriptors: Aged; International Classification of Functioning, Disability and Health; Geriatric Assessment; Nursing.

Objetivo: validar categorias da Classificação Internacional de Funcionalidade, Incapacidade e Saúde direcionadas às pessoas idosas. Métodos: estudo metodológico realizado com 13 enfermeiras brasileiras gerontólogas. Utilizou-se um formulário eletrônico, subsidiado na Classificação Internacional de Funcionalidade, Incapacidade e Saúde, composto por 107 itens (45 relacionados às Funções do corpo; 38 à Participação e Atividade; 24 ao Ambiente), encaminhado por e-mail. Os itens foram avaliados em uma escala likert de cinco pontos variando de 0 a 1,0. Consideraram-se questões validadas aquelas com 80,0\% e mais de aparição. Resultados: foram validadas 21 categorias relacionadas às Funções do Corpo; 18 categorias relacionadas à Participação e Atividade; três categorias relacionadas aos Fatores Ambientais. Conclusão: a formação biomédica na enfermagem pode ter direcionado maior validação das categorias relacionadas ao corpo e menor ao contexto/ambiente.

Descritores: Idoso; Classificação Internacional de Funcionalidade, Incapacidade e Saúde; Avaliação Geriátrica; Enfermagem.

\footnotetext{
${ }^{1}$ Universidade Federal do Rio Grande. Rio Grande, RS, Brazil.

${ }^{2}$ Universidade Católica de Pelotas. Pelotas, RS, Brazil. 


\section{Introduction}

Aging of the world population has been accelerated in recent times. In Brazil, the average life expectancy is increasing annually due to more effective control of environmental risks, improvement of medical interventions, decreased birth rates and mortality rates in recent decades ${ }^{(1)}$. Decreased physical and cognitive ability, which can be influenced by genetic and cultural factors and life habits, is sometimes seen to happen with the aging $\operatorname{process}^{(2)}$.

Increase the participation of older people in society emerges as a challenge, emphasizing that some practices that can minimize the appearance of chronic diseases that frequently affect these people and can lead them to functional disability are very important. It is necessary that the concept of health may value social, economic and cultural factors that affect the health and the individual behavior of the elderly ${ }^{(3)}$.

There is a need for restructuring health systems and to adapt them to the needs of older people, with regard to functionality. The National Health Policy for the Elderly has as one of its priorities the functional evaluation of the elderly, for planning actions that meet the real needs of these people ${ }^{(4)}$.

Functional evaluation of the elderly is part of the clinical management and aims to assess various dimensions such as the very functional capacity, physical health, cognitive function and emotional state, in addition to social and environmental conditions. It is a multidimensional, dynamic and usually multidisciplinary diagnostic process directed to quantify and qualify the problems and needs of the elderly ${ }^{(5)}$.

There are tools to assess the health of people and there is a need for health professionals/nurses to use specific ways of assessment to consider functionality, disability and health of the elderly. The International Classification of Functioning, Disability and Health stands out among these tools. This is characterized as an international model to classify the impact of diseases on the health condition of people. This is an appropriate tool for identifying the structural and environmental conditions and individual characteristics that interfere with the functionality of people ${ }^{(6)}$, including the elderly.

The model of the International Classification of Functioning, Disability and Health needs to be investigated in the social, political and cultural dimensions. It represents a challenge for all in the sense of exploring the acceptability, validity and impact on different systems, particularly exploring the potential for reformulation of policies that may be more inclusive and equitable ${ }^{(7)}$.

Research studies have used the International Classification of Functioning, Disability and Health in various ways and have focused on various aspects, such as: the biopsychosocial proposal focused on the capacity and possibilities like the guide for research ${ }^{(8)}$; for comparison with other instruments or as the main instrument $^{(9)}$; as axis theme for literature research ${ }^{(10)}$.

Some countries have taken measures for the development of a set of strategies to implement the International Classification of Functioning, Disability and Health. These strategies describe the creation of teaching material, the application of the check list, the development of core sets, the financial support for research projects and the introduction of the Classification in university curricula ${ }^{(11)}$. In Brazil, research has used the International Classification of Functioning, Disability and Health, with the human functioning as one advantages of this application ${ }^{(12)}$.

The present study had the objective to validate categories of the International Classification of Functioning, Disability and Health directed to the elderly.

\section{Methods}

Methodological study, method of acquisition, organization and analysis of data, based on the development, adaptation, validation and evaluation of tools. It has application in all forms of scientific knowledge, being relevant in underexplored topics 
when the researcher seeks to build instruments to measure key variables for a given object of study ${ }^{(13)}$.

The survey was conducted in two phases, first phase: preparation of the instrument containing important categories to evaluate the elderly. The categories come from the International Classification of Functioning, Disability and Health; second phase: validation of categories by gerontologist nurses.

In the first phase of the research, the instrument was prepared by eight members of a group of study and research, among them two experts in gerontology by the Brazilian Society of Geriatrics and Gerontology. The instrument was composed of 107 categories (45 related to body function, 38 related to participation and activity, 24 related to the environment). The instrument was presented by means of a Likert scale whose scores ranged as follows: never necessary $=0$; rarely necessary $=0.25$; sometimes necessary $=0.50$; often necessary $=0.75 ;=1.00$ always necessary.

This instrument was developed based on the International Classification of Functioning, Disability and Health - Portugal version ${ }^{(6)}$ and, therefore, it was necessary to sent it for vernacular correction to the Brazilian Portuguese. This phase, called validation of face, corresponds to the moment when experts check whether the data collection instrument questions present adequate form and vocabulary for the purpose of measurement ${ }^{(14)}$. Validation was carried out by five members of the study group and research of the authors of this article, who already had used and/or were using the Classification of Functioning, Disability and Health in dissertations and theses.

After validation, it was found that the instrument was long and in order to facilitate the delivery to participants and their reply, in the second phase of the research was designed an online form using Google Doc platform.

Nurses who have PhD in healthcare of elderly participated in the second phase of the study. Inclusion criteria were: professional with $\mathrm{PhD}$ in elderly health/ aging/old age, found through the website of the Brazilian Society of Geriatrics and Gerontology; and/ or leader/member of study groups and research on aging, found through the site National Research Council.

Fifty two nurses who met the inclusion criteria were found through curricula Lattes. An e-mail inviting nurses to participate in the study was sent to each of the 52 researchers. Among them, 31 accepted the invitation, becoming candidates as possible participants. They received an emailgiving instructions about completing the electronic form, sending them a link for returning the responses and the Informed Consent. The deadline of 15 days was established for reply. When necessary, questions were clarified with the help of one of the researchers, through email or Skype. Only 13 nurses filled and returned the electronic form. Then, a content validation took place, when a group of experts checks whether the items of the data collection instrument represent the content about what one wants to evaluate ${ }^{(14)}$.

Data were organized in tables and processed in an electronic database in the program Microsoft ${ }^{\circledR}$ Excel 2007 (Operating System Windows XP, Microsoft Corporation, Inc.). In the data analysis, elements of described statistics and absolute averages were considered. The categories that reached $80.0 \%$ of agreement were considered validated by the 13 specialists, following guidance from previous research, which also used methodological study ${ }^{(14)}$.

The study complied with the formal requirements contained in the national and international regulatory standards of research involving human beings.

\section{Results}

As for the profile of the 13 nurses who participated in the second phase of the study, all were female, all had PhD in nursing and were active in the 
field of gerontology. Three were fellows in research productivity of the National Research Council. Four were experts in gerontology, from the title contest of the Brazilian Society of Geriatrics and Gerontology. Among the participants, 12 were professors and one was a clinical nurse. Nine nurses had more than 51 years of age. Seven have obtained their nursing graduation for over 26 years. Seven had more than 20 years of experience with the elderly.
Initially, the data collection instrument had 107 categories, and after validation by the gerontologist nurses, 42 categories were retained in the final version of the instrument. Some important categories for the functional evaluation of elderly, in the view of the authors, were not validated by research participants. The following figures show the categories related to the body, participation/activity, environmental factors and respective percentage.

\begin{tabular}{|c|c|}
\hline Categories related to body functions & $\%$ \\
\hline 1. Functions of orientation in relation to: the time, the place, the person. & 100.0 \\
\hline 2. Functions of sleep: amount, beginning, maintenance and quality. & 92.0 \\
\hline 3. Functions of attention: maintenance and change. & 90.0 \\
\hline 4. Functions of memory: short and long term. & 100.0 \\
\hline 5. Functions of perception: hearing, visual, tactile, spatial vision. & 100.0 \\
\hline 6. Mental functions of language: reception of oral language. & 94.0 \\
\hline $\begin{array}{l}\text { 7. Sensory functions: vision, hearing, vestibular (position, balance, movement), tinnitus, vertigo, dizziness or sensation of } \\
\text { falling, nausea, sensitivity to temperature, to pressure, to noxious stimuli. }\end{array}$ & 96.0 \\
\hline 8. Sensation of pain - widespread pain. & 92.0 \\
\hline 9. Cardiac functions: frequency and rhythm. & 100.0 \\
\hline 10. Functions of blood pressure: increased, decreased, maintained. & 100.0 \\
\hline 11. Breath functions: rhythm, depth. & 100.0 \\
\hline 12. Functions of exercise tolerance: strength, aerobic capacity, fatigue. & 88.0 \\
\hline 13. Intake functions: bite, chew, manipulating food in the mouth, swallowing. & 100.0 \\
\hline 14. Defecation functions: elimination, consistency, frequency, continence. & 100.0 \\
\hline 15. Weight maintenance functions. & 86.0 \\
\hline 16. Water balance functions - maintenance. & 88.0 \\
\hline 17. Thermoregulatory functions: body temperature, temperature maintenance. & 98.0 \\
\hline 18. Urination functions: urination, frequency, continence. & 100.0 \\
\hline 19. Sexual functions: discomfort associated with menopause. & 82.0 \\
\hline 20. Functions of joint mobility: general mobility of the joints, general stability of the joints, trembling. & 100.0 \\
\hline 21. Functions of the skin and related structures: reparative, sensations related to the skin. & 86.0 \\
\hline
\end{tabular}

Figure 1 - Categories of components of the International Classification of Functioning, Disability and Health in the Body Functions 


\begin{tabular}{|c|c|}
\hline Categories related to Activity and Participation & $\%$ \\
\hline 1. Intentional sensory experiences: listening. & 82.0 \\
\hline 2. Application of knowledge: to focus attention. & 80.0 \\
\hline 3. Take decisions. & 82.0 \\
\hline 4. Run the daily routine: managing daily routine, complete daily routine, manage their own level of activity. & 80.0 \\
\hline 5. Dealing with stress and other psychological situations; dealing with crises. & 82.0 \\
\hline 6. Communication: communicate and receive spoken messages. & 92.0 \\
\hline 7. Conversation: talk to a person. & 92.0 \\
\hline 8. Changing basic body position: lie down, sit, stand up, bend over, stay seated, stay standing. & 100.0 \\
\hline 9. Self Transference: in sitting position, when lying down. & 100.0 \\
\hline 10. Walk: short distances. & 100.0 \\
\hline 11. Move: inside the house, outside the house and in other buildings, use transportation. & 94.0 \\
\hline $\begin{array}{l}\text { 12. Self-care: wash oneself, dry up oneself, take care of the skin, take care of the teeth, take care of the hair and shaving, take } \\
\text { care of the fingernails, take care of toenails. }\end{array}$ & 100.0 \\
\hline 13. Care related with the process of excretion: regulation of urination. & 100.0 \\
\hline 14. Dress up: dress up clothes, get undressed, put on shoes, take off shoes, chose clothes. & 100.0 \\
\hline 15. Take care of own health: ensure own physical comfort, control food and fitness, maintain health. & 94.0 \\
\hline 16. Community life: informal associations. & 90.0 \\
\hline 17. Recreation and leisure: hobbies, socializing. & 90.0 \\
\hline 18. Religion and spirituality: organized religion, spirituality. & 100.0 \\
\hline
\end{tabular}

Figure 2 - Categories of components of the International Classification of Functioning, Disability and Health in Activity and Participation

\begin{tabular}{|l|c|}
\hline Categories related to Environment & $\%$ \\
\hline $\begin{array}{l}\text { 1. Products and technologies, products or substances for personal use: food, medicine. } \\
\text { 2. Natural environment and man-caused environmental change: climate/temperature. }\end{array}$ & 82.0 \\
\hline $\begin{array}{l}\text { 3. Support and relationships: family; friends; acquaintances, peers, colleagues, neighbors and community members; personal } \\
\text { care providers and personal assistants; health professionals. }\end{array}$ & 100.0 \\
\hline
\end{tabular}

Figure 3 - Categories of components of the International Classification of Functioning, Disability and Health in Environmental Factors 


\section{Discussion}

The International Classification of Functioning, Disability and Health has the potential to measure the health and the inability of people individually or collectively, considering the dimensions of the body, activity/participation and environmental factors ${ }^{(15)}$. It uses a biopsychosocial approach in an attempt to achieve more satisfactory manner the biological, individual and social health of a particular person/ population ${ }^{(16)}$.

Among the 45 categories related to body function, 21 were validated by the nurses. Body functions are the physiological functions of body systems, including psychological functions. Body refers to the human organism as a whole ${ }^{(6)}$.

Among the 38 categories related to participation and activity, 18 were validated by the research participants. It appears that activity is the execution of a task or action by a person and the participation is the involvement in a given situation of life ${ }^{(6)}$.

Among the 24 categories related to the environment, only three were validated by the nurses. These make up the physical, social and attitudinal environment in which people live and conduct their life and that can influence positively or negatively on the performance in society, the ability to perform actions or tasks and the functions and the person's body structures ${ }^{(6)}$.

In a research conducted in Portugal carried out to identify the categories of the International Classification of Functioning, Disability and Health mostly referred to classify the population aged at 65 and older, it was observed, in line with the current study, in the functions of the Body: global mental functions; specific mental functions; vision and related functions; functions of the cardiovascular system; functions of the respiratory apparatus; functions related to the digestive tract ${ }^{(15)}$.

The results of this study showed that nurses who validated the categories focused attention on preferably those related to body functions. This data is similar to that found in the aforementioned review ${ }^{(15)}$. We relate this trend to the biomedical training, which is still being stimulated in the formation of undergraduate courses in Nursing. There is a need to diminish the gap between the most modern concepts of functionality, which include the participation and influence of environmental factors.

The conceptual paradigm of the International Classification of Functioning, Disability and Health tends to offer the different, avoiding the reductionism of biomedical and social models, promoting a comprehensive, integrative and universal perspective of functionality where the person interacts with the physical, social and attitudinal environment ${ }^{(17)}$.

There is a need for more studies using the International Classification of Functioning, Disability and Health in nursing care, especially with regard to its use in the evaluation of patients, demonstrating the capacity of nurses in their specific activities. It is necessary that the International Classification of Functioning, Disability and Health be expanded in nursing, with a view to including this knowledge to those already established in the area of action of nurses $^{(18)}$.

The International Classification of Functioning, Disability and Health becomes relevant as the content taught in training courses for nurses. The biopsychosocial approach of the International Classification of Functioning, Disability and Health proves to be necessary for aspects of care as it provides a multi-dimensional look.

Bibliographical research showed that in the area of nursing, the International Classification of Functioning, Disability and Health has been used for nursing rehabilitation, which is privileged area in the teaching and practice of Europe and in occupational health $^{(19)}$. It is essential to develop and encourage activities that may strengthen the social reintegration of the elderly, helping them to improve in physical, mental and social aspects. In order to achieve this goal, we need joint efforts of different health professionals. The International Classification of Functioning, 
Disability and Health proposes a new paradigm of functionality and disability, as it seeks to avoid reductionism and to promote a comprehensive, integrative and universal perspective of functioning and disability ${ }^{(15)}$.

With regard to the elderly person, the International Classification of Functioning, Disability and Health is an interesting tool to be used by health professionals/nurses, regarding the evaluation of older people. This can contribute to building instruments to be used in the assessment of such persons; to determine the epidemiological profile of the functionality of the elderly and the redesign of nursing care needs ${ }^{(20)}$.

It is important to think in the nursing care directed to the elderly, addressing the International Classification of Functioning, Disability and Health as an important instrument of work, aiming at its power in the contribution to nursing, health, individual, collective, environmental and mainly gerontologytechnological actions ${ }^{(20)}$.

As limitation of this study, there was a small number of participants for the validation of the categories of the International Classification of Functioning, Disability and Health has a result of the extensive electronic form.

\section{Conclusion}

Validations of categories performed by nurses were more frequent in those related to Body Functions, showing the biomedical influence on the training of nurses. Then the categories entered in activity and participation were the second option of the study participants. In terms of contextual/environmental factors, only three out of the 24 categories presented were validated, showing the need to diminish the gap between the most modern concepts of functionality, which include the participation and influence of environmental factors, as suggested by the International classification of Functioning, Disability and Health.

\section{Collaborations}

Santos SSC contributed to the conception and design or analysis and interpretation of data, writing of the article or revising it critically for important intellectual content and final approval of the version to be published. Ilha S, Barlem ELD, Gautério-Abreu DP, Silva BT and Alves IS contributed to the writing of the article, relevant critical review of the intellectual content and final approval of the version to be published.

\section{References}

1. Faria CA, Lourenço RA, Ribeiro PCC, Lopes CS. Cognitive performance and frailty in older adults clients of a private health care plan. Rev Saúde Pública. 2013; 47(5):923-30.

2. Ferreira PCS, Tavares DMS, Rodrigues RAP. Sociodemographic characteristics, functional status and morbidity among older adults with and without cognitive decline. Acta Paul Enferm. 2011; 24(1):29-35.

3. Organização Mundial da Saúde. Knowledge translation framework for ageing and health. Department of Ageing and Life-Course [Internet]. 2012 [cited 2014 Ago. 5]. Available from: http:// www.who.int/ageing/publications/knowledge_ translation.pdf

4. Ministério da Saúde (BR). Portaria n. 2.528, de 19 de outubro de 2006. Política Nacional de Saúde da Pessoa Idosa. Brasília: Ministério da Saúde; 2006.

5. Machado FN, Machado AN, Soares SM. Comparison between ability and performance: a study on the functionality of dependent elderly individuals. Rev Latino-Am Enfermagem. 2013; 21(6):1321-9.

6. Organização Mundial da Saúde. Classificação Internacional de Funcionalidade, Incapacidade e Saúde (CIF). Lisboa: Organização Mundial da Saúde; 2004.

7. Fontes AP, Fernandes AA, Botelho MA. Funcionalidade e incapacidade: aspectos conceptuais, estruturais e de aplicação da Classificação Internacional de Funcionalidade, Incapacidade e Saúde (CIF). Rev Port Saúde Pública. 2010; 28(2):171-8. 
8. Rubio MHG. El desempeño sensorial de un grupo de pre-escolares y escolares con dificultades en las actividades cotidianas. Rev Fac Med. 2010; 58(4):283-92.

9. Casteneda L, Plácido T. Link between the King's Health Questionnaire and the International Classification of Functioning, Disability and Health, for the evaluation of patients with urinary incontinence after gynecological oncology surgery. Acta Fisiatr. 2010; 17(1):18-21.

10. Lima A, Viegas CS, Paula MEM, Silva FCM, Sampaio RF. A qualitative approach of interactions between the domains of the International Classification of Functionality, Disability, and Health. Acta Fisiatr. 2010; 17(3):94-102.

11. Andrade PMO. Avaliação do estágio da fisioterapia conforme as diretrizes curriculares e a perspectiva biopsicossocial da Organização Mundial de Saúde. Avaliação. 2010; 15(2):121-34.

12. Brasileiro IC, Moreira TMM, Buchalla CM. Classificação Internacional de Funcionalidade, Incapacidade e Saúde. Acta Fisiátr. 2013; 20(1):3741.

13. Gray DE. Pesquisa no mundo real. Porto Alegre: Penso; 2012.

14. Ramalho Neto JM, Fontes WD, Nóbrega MML. Instrumento de coleta de dados de enfermagem em Unidade de Terapia Intensiva Geral. Rev Bras Enferm. 2013; 66(4):535-42.
15. PereiraC, FonsecaC, Escova LA, Lopes M.Contributo para a classificação da funcionalidade na população com mais de 65 anos, segundo a Classificação Internacional de Funcionalidade. Rev Port Saúde Pública. 2011; 29(1):53-63.

16. Dale C, Prieto-Merino D, Kuper H, Adamson J, Bowling A, Ebrahim S, et al. Modelling the association of disability according to the WHO International Classification of Functioning, Disability and Health (ICF) with mortality in the British Women's Heart and Health Study. J Epidemiol Community Health. 2012; 66(2):170-5.

17. Carvalho FN, Koifmann RJ, Bergmann A. International Classification of Functioning, Disability, and Health in women with breast cancer: a proposal for measurement instruments. Cad Saúde Pública. 2013; 29(6):1083-93.

18. Florin J, Ehrenberg A, Ehnfors M, Björvell C. A comparison between the VIPS model and the ICF for expressing nursing content in the health care record. Int J Med Inform. 2013; 82(2):108-17.

19. Piexak DR, Cezar-Vaz MR, Bonow CA, Santos SSC. How nurses are using the International Classification of Functioning, Disability and Health: an integrative review. Aquichan. 2015; 15(3):351-67.

20. Quintana JM, Zimmer E, Santos SSC, Pelzer MT, Barros EJL, Lopes MJ. A utilização da Classificação Internacional de Funcionalidade, Incapacidade e Saúde no cuidado aos idosos. Rev Enferm Ref. 2014; IV(1):145-52. 